\title{
MANAJEMEN PEMBELAJARAN AKTIF BERBASIS KARAKTER
}

\section{ACTIVE LEARNING MANAGEMENT BASED ON CHARACTERS}

\author{
S Febriantina1a \\ 1 Universitas Negeri Jakarta, Jakarta Timur, Indonesia \\ a Korespondensi: Susan Febriantina, Email: susanfebriantina@unj.ac.id \\ (Diterima: 22-09-2018; Ditelaah: 22-09-2018; Disetujui: 17-10-2018)
}

\begin{abstract}
This research is to get factual data about the planning, implementation, supervision, and some problems of character-based active learning management at independent curriculum 2013 junior high schools in Depok. This research uses descriptive method. The result showed that character-based active learning management consists of learning planning, implementation, and supervisions which derived from unique school values.
\end{abstract}

Key words: active learning, character education, management.

\begin{abstract}
ABSTRAK
Penelitian ini bertujuan untuk mendapatkan data faktual tentang perencanaan, pelaksanaan, pengawasan, dan berbagai hambatan manajemen pembelajaran aktif berbasis karakter pada Sekolah Rintisan Kurikulum 2013 Mandiri. Penelitian ini menggunakan metode deskripsi. Hasil penelitian menunjukkan bahwa manajemen pembelajaran aktif berbasis karakter di Sekolah Rintisan Kurikulum 2013 Mandiri di Depok terdiri atas perencanaan, pelaksanaan, dan pengawasan pembelajaran yang bersumber pada nilai-nilai khas masing-masing sekolah.
\end{abstract}

Kata kunci: manajemen, pembelajaran aktif, pendidikan karakter.

Febriantina, S. (2018). Manajemen Pembelajaran Aktif Berbasis Karakter. Jurnal Sosial Humaniora 9(2): 127-137.

\section{PENDAHULUAN}

Digulirkannya pendidikan karakter pada kurikulum 2013 bukan berarti pelaksanaan pendidikan karakter disekolah sudah berjalan sebagaimana mestinya. Hal ini disebabkan oleh beberapa hal diantaranya: Pertama, banyak guru yang beranggapan bahwa pendidikan karakter merupakan mata pelajaran baru dan berdiri sendiri; Kedua, banyak guru yang beranggapan bahwa pendidikan karakter merupakan pengganti mata pelajaran Pendidikan Kewarganegaraan (PKn) atau Budi Pekerti dan Pendidikan Agama yang sudah ada sebelumnya. Akibatnya banyak yang mencoba menyamakan metode pembelajaran seperti yang banyak dipakai yaitu metode ceramah dan catat; Ketiga, banyak guru yang beranggapan bahwa pendidikan karakter adalah tugas dari guru mata pelajaran Agama dan PKn saja serta kalau perlu melibatkan guru BK sekiranya terjadi masalah yang terkait dengan karakter siswa; Keempat, banyak guru yang beranggapan bahwa pendidikan karakter hanyalah pelengkap atau tambahan saja sehingga tidak perlu diprioritaskan seperti halnya dengan materi akademis; dan Kelima, banyak yang beranggapan bahwa pendidikan karakter hanyalah sebuah pengetahuan semata (kognitif) sehingga 
tidak perlu usaha yang khusus dan terencana.

Hal di atas senada dengan Fasli Jalal (2006;1) bahwa kekeliruan-kekeliruan seperti inilah yang telah menghambat pelaksanaan pendidikan karakter di sekolah. Akibatnya dalam beberapa tahun sejak dicanangkannya pendidikan karakter pada kurikulum 2013 belum banyak mendapatkan kemajuan yang diperoleh. Ini artinya, pendidikan karakter masih tetap perlu disempurnakan kembali pelaksaanaannya. Penelitian sebelumnya yang dilakukan oleh Berkowitz (2001:29) juga menunjukkan bahwa banyaknya kekeliruan terkait pemahaman pendidikan karakter di Amerika dan beberapa negara lainnya memunculkan berbagai usaha penyempurnaan kembali pendidikan karakter yang banyak di dukung oleh pemerintah, badan legislatif dan univiersitas. Sayangnya, bermunculannya perhatian pembuat kebijakan terhadap pendidikan karakter kurang disambut dengan baik oleh pihak satuan pendidikan. Benninga (2006: 448) menyatakan bahwa tidak sedikit pihak sekolah merasa ragu dengan kemunculan pendidikan karakter yang berimbas pada peningkatan kinerja mereka.

Di sisi lain sekolah sebagai pusat pembudayaan melalui pendekatan pengembangan budaya sekolah (school culture) menjadi sarana utama dalam penerapan pendidikan karakter. Menyadari pentingnya penerapan pendidikan karakter di sekolah sebagai sarana pengembangan budaya, beberapa sekolah di kota Depok mencoba menerapkan kurikulum 2013 secara mandiri yang di anggap lebih mengakomodir pendidikan karakter di dalamnya. Sekolah-sekolah tersebut secara mandiri menerapkan kurikulum 2013 meski tidak ditunjuk oleh dinas pendidikan setempat, sebagaimana beberapa sekolah yang ditunjuk (piloting) sebagai sekolah pelaksana kurikulum 2013.

Badan Pusat Statistik Balitbang 2015 menyatakan bahwa untuk tingkat Sekolah Dasar di kota Depok terdapat tiga sekolah yang telah mendapatkan Surat Keputusan sebagai Sekolah Dasar Rintisan Kurikulum 2013 Secara Mandiri, sementara untuk tingkat Sekolah Menengah Pertama terdapat sepuluh sekolah yang tersebar hampir di semua kecamatan di kota Depok. Uniknya, sekolah-sekolah yang mengajukan diri secara mandiri sebagai sekolah rintisan penerapan Kurikulum 2013 adalah sekolahsekolah yang sebelumnya memang telah lama menerapkan pendidikan karakter jauh sebelum pemerintah menggemborgemborkan pendidikan karakter, sehingga sekolah-sekolah tersebut dengan optimis mengajukan diri sebagai sekolah rintisan penerapan Kurikulum 2013 disaat sekolah lain masih ragu, bahkan belum siap dengan adanya perubahan KTSP ke Kurikulum 2013.

Bermunculnya SMP Rintisan Kurikulum 2013 Mandiri di Kecamatan Beji Kota Depok menjadi sesuatu hal yang langka dan unik mengingat baru sedikit sekolah di kota Depok yang siap menerapkan kurikulum 2013. Berdasarkan Surat Keputusan Kepbalitbang Kemendikbud RI nomor 022H/KR/2015 terdapat sebelas sekolah swasta yang menerapkan Kurikulum 2013 Secara Mandiri di Kota Depok.

Manajemen pembelajaran aktif berbasis karakter belum banyak di diterapkan oleh satuan pendidikan di Indonesia. Padahal para ahli pendidikan karakter telah banyak menyatakan pentingnya pembelajaran aktif berbasis karakter dapat diterapkan di setiap satuan pendidikan.

\section{MATERI DAN METODE}

Penelitian ini dilakukan di SMP Rintisan Kurikulum 2013 Mandiri Kecamatan Beji Kota Depok. Populasi penelitian ini mencakup SMP Rintisan Kurikulum 2013 Mandiri se-Kecamatan Beji Kota Depok yang telah diberikan SK Kepbalitbang Kemendikbud RI nomor 022H/KR/2015 sebagai sekolah yang diberikan wewenang untuk menerapkan kurikulum 2013 secara mandiri sejumlah 60 orang yang terdiri atas 
para guru dan kepala sekolah di SMPIT Ummu'l Quro dan SMP Putra Bangsa. Pengambilan sampel yang dilakukan dalam penelitian ini adalah teknik pengambilan sampel proportional random sampling. Disamping mengambil sampel sebanyak 49 orang guru, peneliti juga melakukan wawancara kepada dua orang kepala sekolah dan dua orang perwakilan peserta didik dari masing-masing sekolah.

Adapun data sekunder yang digunakan berupa dokumen dan rekaman arsip yang terkait dengan peraturan pemerintah tentang standar proses, panduan pendidikan karakter, silabus dan rencana pelaksanaan pembelajaran (RPP) kurikulum 2013 maupun dokumen-dokumen lainnya yang terkait. Teknik dan prosedur pengumpulan data yang digunakan menggunakan beberapa sumber bukti, yakni penyebaran angket, wawancara mendalam, studi dokumentasi dan arsip. Teknik pengumpulan data tersebut dalam penggunaannya dapat saling melengkapi dan menunjang sehingga dapat diperoleh informasi yang diperlukan (Silverman,1994;9).

Penyebaran angket tertutup dan terbuka diberikan kepada para guru sebagai informan utama sementara wawancara mendalam dilakukan kepada kepala sekolah. Wawancara terbatas juga dilakukan kepada perwakilan peserta didik dari kedua sekolah tersebut. Studi dokumentasi dilakukan dengan cara mengkaji berbagai dokumen yang mencakup tujuan tertulis, program atau rencana yang telah disusun, perangkat pelaksanaan program, dan bukti/hasil yang telah dicapai dan laporan yang telah dibuat. Adapun penyusunan angket tertutup dan terbuka dan pedoman wawancara berdasarkan Permen 65 tahun 2013 tentang Standar Proses Pendidikan Dasar dan Menengah.

\section{HASIL DAN PEMBAHASAN}

\section{Perencanaan Pembelajaran Aktif Berbasis Karakter}

Guru-guru di SMP Rintisan Kurikulum 2013 Mandiri di Kecamatan Beji Kota Depok sudah dapat merencanakan perencanaan pembelajaran dengan baik, meski konsistensinya dalam merumuskan perencanaan pembelajaran aktif yang mengandung nilai-nilai karakter masih memerlukan peningkatan. Hal ini terlihat dari hasil angket tertutup dan terbuka para guru serta wawancara mendalam dengan para kepala sekolah terkait perencanaan pembelajaran yang mereka susun. Beberapa aspek dilakukan secara konsisten dalam perencanaan tersebut, namun beberapa aspek lainnya masih belum konsisten dilakukan sehingga masih harus terus ditingkatkan.

Kenyataan bahwa sebagian besar guru telah mengembangkan nilai-nilai karakter dalam perencanaan pembelajarannya, terutama dalam KI 1, 2, 3 dan 4 telah sesuai dengan peraturan Pedoman Sekolah 2009 terkait Pengembangan dan Pendidikan Budaya dan Karakter Bangsa KI sikap spiritual bertujuan menerima, menjalankan, dan menghargai ajaran agama yang dianut para peserta didik. KI 2 bertujuan menunjukkan perilaku jujur, disiplin, tanggung jawab, santun, peduli, dan percaya diri dalam berinteraksi dengan keluarga, teman, guru, dan tetangganya. KI 3 bertujuan memahami pengetahuan faktual dengan cara mengamati dan menanya berdasarkan rasa ingin tahu tentang dirinya, makhluk ciptaan Tuhan dan kegiatannya, serta benda-benda yang dijumpainya di rumah, di sekolah dan tempat bermain peserta didik. Sementara KI 4 bertujuan menyajikan pengetahuan faktual dalam bahasa yang jelas, sistematis dan logis, dalam gerakan yang mencerminkan anak sehat, dan dalam tindakan yang mencerminkan perilaku anak beriman dan berakhlak mulia. 
Berdasarkan penjabaran di atas, dapat disimpulkan bahwa perencanaan pembelajaran aktif berbasis karakter di SMP
Rintisan Kurikulum 2013 Mandiri SeKecamatan Beji Depok dapat dilihat pada tabel 1.

Tabel 1 Perencanaan pembelajaran aktif berbasis karakter di SMP Rintisan Kurikulum 2013 Mandiri Se-Kecamatan Beji Depok

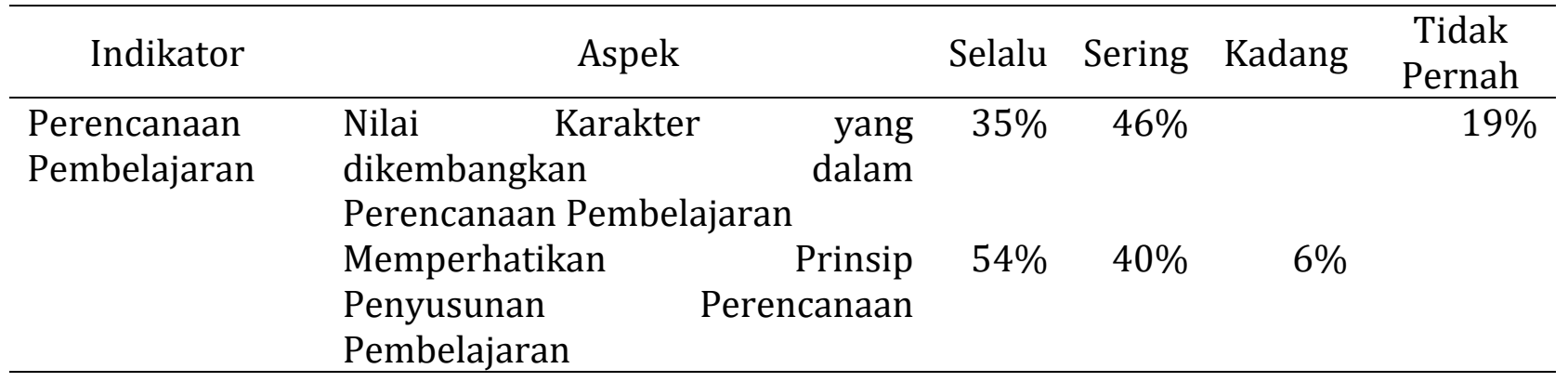

Hasil penelitian di atas selaras dengan pendapat (Robbins dan Coulter, 2012; 232) bahwa sebuah perencanaan membahas tentang definisi tujuan organisasi, penetapan strategi untuk mencapai tujuan, mengembangkan rencana untuk mengintegrasikan dan mengkoordinasikan kegiatan kerja. Hal ini juga mendukung pendapat yang disampaikan Bonwell and Eison (1991:1) perencanaan pembelajaran aktif berkaitan dengan kata (apa) dan cara (bagaimana) memulai ibahwa ndikator perencanaan pembelajaran aktif berbasis karakter yang sudah dilaksanakan para guru diantaranya penyusunan silabus dan RPP yang sesuai sebagaimana mestinya.

Prince (2004:223) dan Yoder dan Hochevar, $(2005 ; 91)$ juga menyatakan bahwa merencanakan pembelajaran harus sebagaimana prinsip-prinsip penyusunan RPP yang memperhatikan perbedaan individual peserta, partisipasi aktif peserta didik pengembangan budaya membaca dan menulis, adanya pemberian umpan balik dan tindak lanjut RPP, adanya penekanan pada keterkaitan dan keterpaduanantara $\mathrm{KD}$, materi pembelajaran, kegiatan pembelajaran, indikator pencapaian kompetensi, penilaian, dan sumber belajar dalam satu keutuhan pengalaman belajar dan penerapan teknologi informasi dan komunikasi secara terintegrasi, sistematis, dan efektif sesuai dengan situasi dan kondisi.
Indikator perencanaan pembelajaran aktif berbasis karakter yang masih belum konsisten dilakukan oleh para guru diantaranya indikator pengembangan nilainilai karakter yang tersusun dengan jelas dalam perencanaan pembelajaran dan indikator dan sejauhmana para guru memperhatikan prinsip-prinsip penyusunan perencanaan pembelajaran yang memuat pembelajaran yang berpusat pada peserta didik, dan mengakomodasi pembelajaran tematik-terpadu, keterpaduan lintas mata pelajaran, lintas aspek belajar, dan keragaman budaya. Hackathorn et all, (2010) berpendapat bahwa memang tidak mudah membuat perencanaan pembelajaran dengan mengembangkan nilai-nilai karakter didalamnya.

Perencanaan pembelajaran yang sudah dilakukan para guru di SMP Rintisan Kurikulum 2013 Mandiri di Kecamatan Beji Kota Depok diatas sudah dilaksanakan dengan baik, sebagaimana konsep perencanaan akan membantu dalam menentukan (1) prioritas berorientasi memastikan hal yang paling penting mendapatkan perhatian pertama, (2) aksi berorientasi, menjaga hasil orientasi, 3) keuntungan berorientasi - memastikan bahwa semua sumber daya digunakan untuk keuntungan yang terbaik, (4) mengubah berorientasi - mengantisipasi masalah dan kesempatan sehingga mereka dapat ditangani (Schermerhorn, 2010; 89). 
Perencanaan yang dibuat sesuai dengan Permen 65 tahun 2013 tentang Standar Proses Pendidikan Dasar dan Menengah yang mengemukakan bahwa, perencanaan pembelajaran dirancang dalam bentuk Silabus dan Rencana PelaksanaanPembelajaran (RPP) yang mengacu pada Standar Isi.

Adapun terkait dengan perencanaan pembelajaran berbasis karakter, silabus dan RPP yang telah dibuat para guru di SMP Rintisan Kurikulum 2013 Mandiri di Kecamatan Beji Kota Depok sudah memuat nilai-nilai karakter dan sesuai dengan prinsip penyusunannya. Hal ini selaras dengan Nuccy dan Narvaez (2008; 55) character education emphasizes the direct teaching of virtues and exemplary character traits, role modeling, and reinforcement of good behavior.

\section{Pelaksanaan Pembelajaran Aktif Berbasis Karakter}

Pelaksanaan pembelajaran aktif berbasis karakter di SMP Rintisan Kurikulum 2013 Mandiri di Kecamatan Beji Kota Depok terlaksana seiring proses perkembangan perbaikan terus menerus. Hal ini terlihat dari hasil angket tertutup dan terbuka yang disebar kepada para guru dan hasil wawancara mendalam kepada kedua kepala sekolah serta beberapa peserta didik yang dapat dilihat pada tabel 2 .

Tabel 2 Pelaksanaan pembelajaran aktif berbasis karakter di SMP Rintisan Kurikulum 2013 Mandiri di Kecamatan Beji Kota Depok

\begin{tabular}{|c|c|c|c|c|c|c|}
\hline Indikator & Sub Indikator & Aspek & Selalu & Sering & Kadang & $\begin{array}{l}\text { Tidak } \\
\text { Pernah }\end{array}$ \\
\hline \multirow[t]{5}{*}{$\begin{array}{l}\text { Pelaksanaan } \\
\text { Pembelajaran }\end{array}$} & $\begin{array}{l}\text { a. Pengelolaan } \\
\text { Kelas }\end{array}$ & $\begin{array}{l}\text { Mengatur tempat } \\
\text { duduk siswa dalam } \\
\text { pengelolaan kelas } \\
\text { berbasis karakter }\end{array}$ & $25 \%$ & $35 \%$ & $38 \%$ & \\
\hline & & $\begin{array}{l}\text { Mengatur volume } \\
\text { dan intonasi suara } \\
\text { dalam pengelolaan } \\
\text { kelas berbasis } \\
\text { karakter }\end{array}$ & $73 \%$ & $27 \%$ & & \\
\hline & & \begin{tabular}{l}
\multicolumn{2}{l}{ Menggunakan } \\
bahasa santun \\
dalam pengelolaan \\
kelas berbasis \\
karakter
\end{tabular} & $56 \%$ & $44 \%$ & & \\
\hline & & $\begin{array}{l}\text { Menyesuaikan } \\
\text { materi dengan } \\
\text { kecepatan belajar } \\
\text { peserta didik dalam } \\
\text { pengelolaan kelas } \\
\text { berbasis karakter }\end{array}$ & $56 \%$ & $36 \%$ & $8 \%$ & \\
\hline & & $\begin{array}{l}\text { Menerapkan } \\
\text { ketertiban, } \\
\text { kedisiplinan, } \\
\text { kenyamanan, dan } \\
\text { keselamatan }(4 \mathrm{~K}) \\
\text { dalam pengelolaan } \\
\text { kelas berbasis } \\
\text { karakter }\end{array}$ & $67 \%$ & $31 \%$ & $2 \%$ & \\
\hline
\end{tabular}




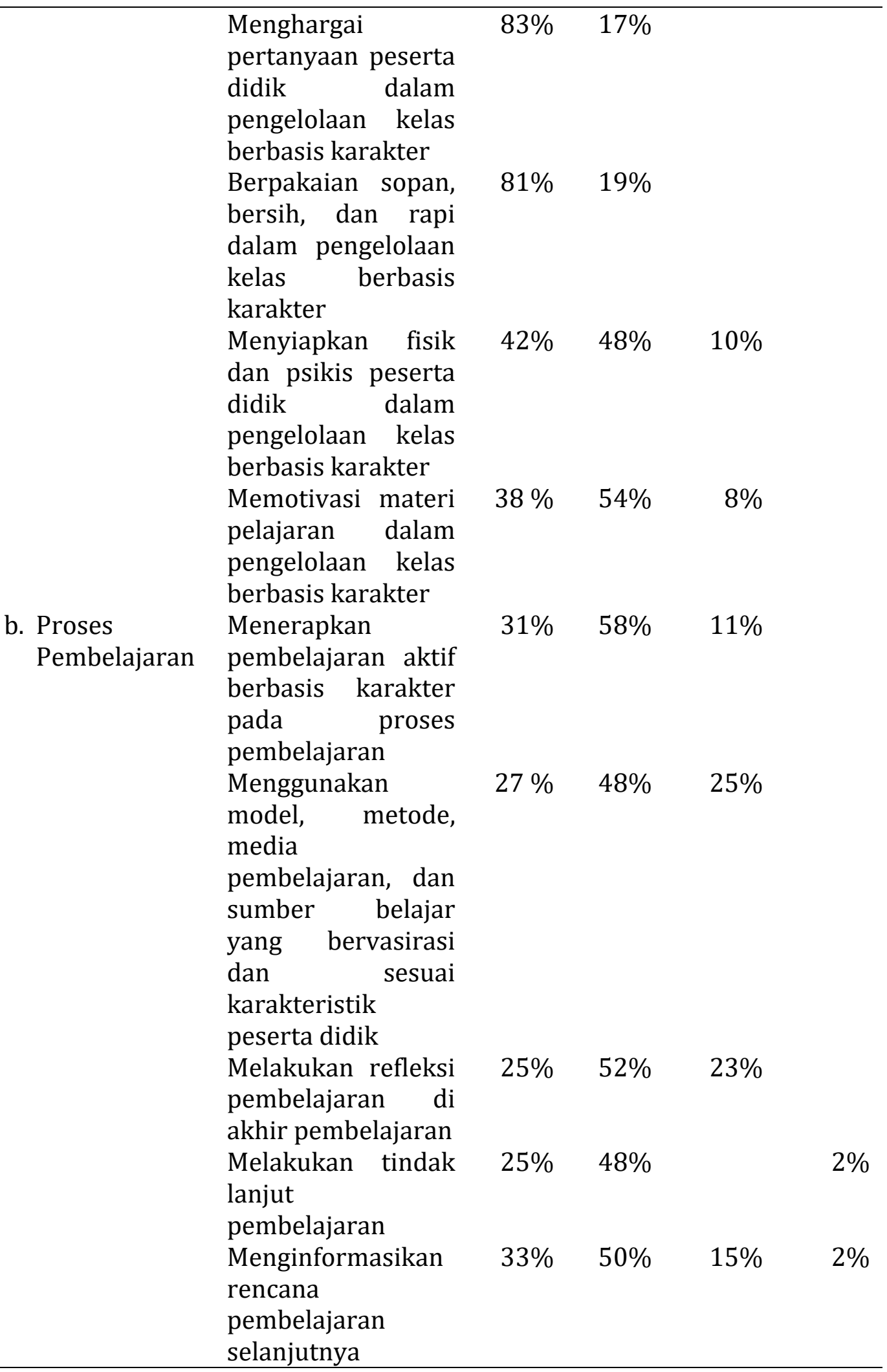

Hasil penelitian menunjukkan bawah indikator yang sudah konsisten dilaksanakan para guru di SMP Rintisan Kurikulum 2013 Mandiri di kecamatan Beji Kota Depok meliputi pelaksanaan pembelajaran. Hal ini selaras dengan
Wingfield, S., \& Black, G. S, (2005; 119) bahwa aspek pelaksanaan pembelajaran aktif meliputi pengelolaan kelas yang mencakup pengaturan volume dan intonasi suara, penggunaan bahasa santun dalam pengelolaan kelas berbasis karakter, 
menghargai pertanyaan peserta didik, berpakaian sopan, bersih, dan rapi dalam pengelolaan kelas berbasis karakter. Adapun indikator proses pelaksanaan pembelajaran yang masih dilakukan secara inkonsisten oleh para guru diantaranya adalah menerapkan pembelajaran aktif berbasis karakter itu sendiri ketika di kelas. Serva\&Fuller $(2010 ; 19)$ menyatakan bahwa inkonsistensi guru serta warga sekolah dalam penerapan pembelajaran akan sangat berpengaruh terhadap kualitas pelaksaaan pembelajaran aktif.

Hal tersebut juga diakui oleh para kepala sekolah di kedua sekolah tersebut dalam wawancaranya, bahwa memang para guru belum sepenuhnya memahami metode dan model-model teknis active learning. Sebanyak 25\% guru mengaku kadangkadang menggunakan model, metode, media pembelajaran, dan sumber belajar yang bervariasi dan sesuai karakteristik peserta didik. Terkait hal ini Zayapragassarazan dan Kumar $(2012 ; 3)$ berpendapat bahwa selebihnya mereka kembali pada model lama yakni ceramah. Media dan sumber pembelajaran pun dirasa masih terbatas sehingga menimbulkan kejenuhan bagi gurunya sendiri.

Di akhir pembelajaran juga masih terdapat guru $25 \%$ guru yang menyatakan kadang-kadang melakukan refleksi pembelajaran. Padahal dalam Peraturan Menteri Pendidikan Nasional Nomor 65 Tahun 2013 tentang Standar Proses untuk Satuan Pendidikan Dasar dan Menengah pembelajaran aktif berbasis karakter, refleksi pembelajaran dinilai sangat penting terutama untuk mengevaluasi a) seluruh rangkaian aktivitas pembelajaran dan hasilhasil yang diperoleh untuk selanjutnya secara bersama menemukan manfaat langsung maupun tidak langsung dari hasil pembelajaran yang telah berlangsung; b) memberikan umpan balik terhadap proses dan hasil pembelajaran; c) melakukan kegiatan tindak lanjut dalam bentuk pemberian tugas, baik tugas individual maupun kelompok; dan d) menginformasikan rencana kegiatan pembelajaran untuk pertemuan berikutnya.

Pengaturan tempat duduk peserta didik seharusnya juga menjadi hal yang diperhitungkan para guru dalam melaksanakan pembelajaran aktif berbasis karakter. Dengan perencanaan pengaturan tempat duduk yang baik, para peserta didik dapat bertukar pendapat dengan temannya, dapat menyelesaikan masalah beserta timnya sehingga tumbuh kemandirian, kereatifitas dan daya kritisnya. Tentunya aktifitas semacam itu memerlukan perencanaan tempat duduk yang matang sebelumnya yang harus direncanakan para guru. Namun pada kenyataannya, sebanyak $38 \%$ guru menyatakan kadang-kadang mengatur tempat duduk peserta didiknya.

Berdasarkan hasil wawancara kepada peserta didik dan kepala sekolah juga diketahui bahwa, proses pembelajaran setiap mata pelajaran yang mencakup kegiatan pendahuluan, inti dan penutup memuat nilai-nilai karakter, seperti misalnya pada kegiatan pendahuluan, peserta didik memulai pembelajaran dengan pendekatan spiritual dan rasa ingin tahu yang tinggi terkait materi pelajaran yang akan disampaikan. Pada kegiatan inti, setiap guru mata pelajaran juga mengkaitkan materi pembelajaran dengan kenyataan sehari-hari dilapangan, dan memunculkan nilai-nilai karakter dalam setiap pembelajaran. Misalnya ketika belajar bahasa inggris, dengan topik disaster, peserta didik ditumbuhkan rasa cinta kepada tanah air nya sehingga muncul kesadaran untuk menjaga lingkungan dengan sebaik-baiknya, demikian pula dengan mata pelajaran lainnya.

Adapun nilai-nilai karater yang dimunculkan dalam pembelajaran aktif lebih banyak di adaptasi dari nilai-nilai setiap sekolah. Misalnya di SMPIT Ummu'l Quro Depok, nilai karakter lebih banyak di dasari oleh nilai-nilai spiritual sebagaimana kekhasan sekolah tersebut. Sementara di SMP Putra Bangsa lebih difokuskan pada nilai-nilai nasionalis yang merupakan ciri khas sekolah tersebut seperti cinta tanah 
air, kerjasama tim, kejujuran, kemandirian, disiplin, kreatifitas dan masih banyak lainnya. Hal tersebut tentunya selaras dengan Pedoman Pengembangan dan Pendidikan Budaya dan Karakter Bangsa yang diterapkan di sekolah-sekolah, bahwa terdapat delapan belas nilai karakter yang senantiasa dikembangkan dalam proses pembelajaran aktif tersebut, yakni (1) Religius, (2) Jujur, (3) Toleransi, (4) Disiplin, (5) Kerja keras, (6) Kreatif, (7) Mandiri, (8) Demokratis, (9) Rasa Ingin Tahu, (10) Semangat Kebangsaan, (11) Cinta Tanah Air, (12) Menghargai Prestasi,
Bersahabat/Komunikatif, (14) Cinta Damai, (15) Gemar Membaca, (16) Peduli Lingkungan, (17) Peduli Sosial, (18) Tanggung Jawab (Pusat Kurikulum. Pengembangan dan Pendidikan Budaya dan Karakter Bangsa, 2009:9-10).

\section{Pengawasan Pembelajaran Aktif Berbasis Karakter}

Pengawasan pembelajaran aktif berbasis karakter di SMP Rintisan Kurikulum 2013 Secara Mandiri Se-Kecamatan Beji Kota Depok dapat dilihat pada tabel 3.

Tabel 3 pengawasan pembelajaran aktif berbasis karakter pada SMP Rintisan kurikulum 2013 Mandiri se-Kecamatan Beji Depok

\begin{tabular}{clccccc}
\hline \multicolumn{1}{c}{ Indikator } & \multicolumn{2}{c}{ Aspek } & Selalu & Sering & Kadang & $\begin{array}{c}\text { Tidak } \\
\text { Pernah }\end{array}$ \\
\hline $\begin{array}{l}\text { Pengawasan } \\
\begin{array}{l}\text { Pembelajaran } \\
\text { Kepala sekolah mensupervisi }\end{array}\end{array}$ & $\begin{array}{l}19 \% \\
\text { pembelajaran } \\
\text { Mendapatkan pelatihan terkait } \\
\text { pembelajaran } \\
\text { pendidikan karakter }\end{array}$ & $\begin{array}{c}12 \% \\
\text { atau }\end{array}$ & $44 \%$ & $37 \%$ & $6 \%$ \\
\hline
\end{tabular}

Berdasarkan hasil penelitian di atas dapat diketahui bahwa pengawasan pembelajaran oleh kepala sekolah sudah terlaksana meski dengan prosentase masih rendah. Padahal funsgi pengawasan juga tidak boleh di abaikan mengingat Daft (2010;45) mengemukakan bahwa pengawasan pembelajaran merupakan rangkaian manajemen pembelajaran yang tidak boleh ditinggalkan. Hal ini selaras dengan pendapat Robbins (2009:415) bahwa pengendalian atau pengawasan adalah proses memantau kegiatan untuk memastikan bahwa apa yang dilakukan sesuai dengan rencana dan ada perbaikan untuk penyimpangan yang signifikan tersebut. Djuharis (2013) juga menyatakan bahwa pengawasan dari pihak kepala sekolah dan atau pengawas sekolah sangat diperlukan dalam rangka mengevaluasi proses pembelajaran aktif berbasis karakter.

Adapun rentang waktu supervisi kepala sekolah ke dalam kelas dalam setahun dapat dihitung kurang lebih satu hingga dua kali, namun ada juga beberapa guru menyatakan tidak pernah atau belum pernah disupervisi sama sekali, yakni sebanyak $6 \%$. Pengawasan pelaksanaan kurikulum 2013 oleh pengawas dinas pendidikan setempat juga dilaksanakan (Ediana, 2013). Satu hingga dua bulan sekali monitoring dari dinas pendidikan datang ke setiap sekolah yang dibina. Setiap sekolah mendapatkan sebelas supervisor yang terdiri atas sembilan supervisor mata pelajaran, satu supervisor kepustakaan, dan satu supervisor labolatorium. Secara teknis, porsi pengawasan oleh dinas pendidikan setempat lebih banyak dilakukan dengan cara sosialisasi dan latihan (workshop) pembuatan rencana pembelajaran (RPP) kurikulum 2013 itu sendiri. Para guru dan kepala sekolah mengaku bahwa idealnya proses pendampingan (pengawasan) tersebut lebih di variasikan lagi kegiatannya, seperti pendampingan metode pembelajaran atau model-model pembelajaran. Namun setiap sekolah juga mengakui, karena keterbatasan masingmasing sekolah dan pihak dinas pendidikan 
setempat juga, akhirnya pendampingan masih sebatas sosialisasi kurikulum 2013 dan RPP, belum pada pelaksanaan pembelajaran dan jadwal pendampingan juga lebih banyak dipadatkan dari seharusnya.

\section{Idealnya} pengawasan

proses pembelajaran dilakukan melalui kegiatan pemantauan, supervisi, evaluasi, pelaporan, serta tindak lanjut secara berkala dan berkelanjutan oleh kepala satuan pendidikan dan pengawas. Pemantauan proses pembelajaran dilakukan pada tahap perencanaan, pelaksanaan, dan penilaian hasil pembelajaran melalui diskusi kelompok terfokus, pengamatan, pencatatan, perekaman, wawancara, dan dokumentasi. Hal ini sebagaimana di tetapkan Permen 65 tahun 2013 tentang Standar Proses Pendidikan Dasar dan Menengah bahwa supervisi proses pembelajaran juga semestinya dilakukan pada tahap perencanaan, pelaksanaan, dan penilaian hasil pembelajaran melalui pemberian contoh, diskusi, konsultasi, atau pelatihan. Adapun pelaporan hasil kegiatan pemantauan, supervisi, dan evaluasi proses pembelajaran semestinya disusun dalam bentuk laporan untuk kepentingan tindak lanjut pengembangan keprofesionalan pendidik secara berkelanjutan.

Berdasarkan pembahasan di atas dapat disimpulkan bahwa secara keseluruhan, pengawasan pembelajaran di SMP Rintisan Kurikulum 2013 Mandiri di Kecamatan Beji Kota dilaksanakan oleh kepala sekolah minimal satu tahun sekali dan dipantau oleh dinas pendidikan setempat dalam bentuk pendampingan dengan rentang waktu pendampingan dua bulan sekali.

Disamping hal di atas terdapat beberapa kendala yang dihadapi oleh SMP Rintisan Kurikulum 2013 Mandiri di Kecamatan Beji Kota Depok dalam melaksanakan pembelajaran aktif berbasis karakter yakni : 1) Pada proses pelaksanaan pembelajaran, para guru masih mempunyai keterbatasan akan penguasaan Information, Communication and Technology (ICT). Tidak sedikit guru di SMP Rintisan Kurikulum
2013 Mandiri di Kecamatan Beji Kota Depok terkendala masalah penguasaan ICT sehingga dalam proses pembelajaran yang seharusnya aktif, kreatif, efektif dan menyenangkan guru belum mampu mengoptimalkan teknologi; 2) Pada proses pengawasan yang terkait dengan penilaian pembelajaran. Sistem penilaian Kurikulum 2013 berbeda dengan sistem penilaian KTSP. Dalam sistem penilaian Kurikulum 2013, setiap mata pelajaran memuat aspek kognisi, afektif dan psikomotorik dan smasing-masing aspek tersebut memuat masing-masing indikator juga yang tidak sedikit jumlahnya. Dengan demikian para guru seharusnya sudah harus menginput nilai sejak awal pembelajaran dilakukan. Namun pada kenyataannya, para guru di SMP Rintisan Kurikulum 2013 Mandiri di Kecamatan Beji Kota Depok belum konsisten menerapkan hal tersebut, sehingga di akhir semester pihak guru dan sekolah keteteran dalam menginput nilai peserta didik.

\section{KESIMPULAN DAN IMPLIKASI}

Berdasarkan hasil dan analisis data, maka dapat diambil kesimpulan bahwa manajemen pembelajaran aktif berbasis karakter di SMP Rintisan Kurikulum 2013 Mandiri di Kecamatan Beji Kota Depok dilaksanakan dengan tiga tahap yakni perencanaa, pelaksanaan, dan pengawasan. Perencanaan pembelajaran aktif berbasis karakter dilaksanakan dengan mengembangkan nilai-nilai karakter pada silabus dan RPP serta memperhatikan prinsip penyusunan perencanaan pembelajaran berbasis karakter. Pelaksanaan pembelajaran aktif berbasis karakter dilakukan dengan menggunakan model, metode, media pembelajaran, dan sumber belajar yang sesuai karakteristik peserta didik melalui pendekatan dan penguatan nilai-nilai karakter. Pengawasan pembelajaran aktif berbasis karakter dilaksanakan oleh kepala sekolah dan pendamping/pengawas dari dinas pendidikan setempat yang meliputi 
supervisi perencanaan, pelaksanaan dan penilaian pembelajaran berbasis karakter.

Selain hal di atas terdapat beberapa kendala yang dihadapi para guru dan kepala sekolah di di SMP Rintisan Kurikulum 2013 Mandiri di Kecamatan Beji Kota Depok dalam melaksanakan kurikulum 2013 mandiri. Kendala tersebut mencakup pelaksanaan pembelajaran dan pengawasan yang meliputi adanya keterbatasan penguasaan Information, Communication and Technology (ICT) yang dapat menghambat pelaksanaan pembelajaran aktif berbasis karakter dan penilaian pembelajaran yang dianggap rumit.

Berdasarkan kesimpulan di atas, maka saran yang perlu ditindak lanjuti antara lain (1) Para guru sebaiknya meningkatkan kompetensinya dalam penguasaaan Information, Communication and Technology (ICT) sehingga hal tersebut tidak menghambat proses pelaksanaan pembelajaran aktif berbasis karakter; (2) Pihak sekolah sebaiknya melakukan pengawasan secara berkelanjutan terhadap pelaksanaan pembelajaran aktif berbasis karakter yang dilakukan para guru guna merumuskan sistem penilaian pembelajaran yang sesuai; (3) Dinas Pendidikan Kecamatan supaya dapat memberikan bimbingan dan pengawasan berlanjut sebagaimana yang diberikan kepada sekolah-sekolah piloting Kurikulum 2013 lainnya; (4) Bagi peneliti lain agar dapat dijadikan sebagai referensi dalam rangka penelitian lanjutan terkait dengan masalah pendidikan karakter. Selain itu dapat memperluas penelitian dengan lebih banyak menggali keunikan dan ciri khas nilai-nilai karakter lainnya.

\section{DAFTAR PUSTAKA}

Benninga et.al Character and Academics: What Good Schools Do, Phi Delta Kappan, Volume: 87 issue: 6, page(s): 448-452 February 1, 2006
Bonwell, C.C., and J. A. Eison, 1991, "Active Learning: Creating Excitement in the Classroom.

David Silverman, Interpreting Qualitative Data; Methods for Analysing Talk, Text and Interaction, (London: Sage Publication, Ltd, 1994), h. 9.

Fasli Jalal, 2016, Makalah Seminar Nasional, Jakarta.

Hackathorn, J., Solomon, E. D., Tennial, R. E., Garczynski, A. M., Blankmeyer, K.,Gebhardt, K. \& Anthony,

Larry P Nuccy dan Darcia Narvaez, Handbook of Moral and Character Education; Moral Education and the Cognitive Development Tradition; Lawrence Kohlberg's Revolutionary Ideas by John Snareyand and Peter Samuelson (Routledge Taylor and Francis, 2008), h.55

Michael Prince. "Does Active Learning Work? A Review of the Reseach", Journal of Engineering Education, 2004, 93 (3), 223-231

Marvin W Berkowitz, What Works on Character Education, Journal of Research in Character Education, Volume 5 (1), 2007, pp 29-48)

Panduan Pelaksanaan Pendidikan Karakter, Kemendiknas, 2011. Permendikbud Nomor 103 Pasal 2 Tahun 2014

Pedoman Sekolah 2009 terkait Pengembangan dan Pendidikan Budaya dan Karakter Bangsa

Peraturan Menteri Pendidikan Nasional Nomor 65 Tahun 2013 tentang Standar Proses untuk Satuan Pendidikan Dasar dan Menengah hal 8-11

Pusat Kurikulum. Pengembangan dan Pendidikan Budaya dan Karakter Bangsa: Pedoman Sekolah. 2009:9-10.

Rasul Djuharis, "Pelaksanaan Pendidikan Karakter, Ekonomi Kreatif, Dan Kewirausahaan Dalam Belajar Aktif di SMK", Jurnal Pendidikan \& Kebudayaan Vol. 19, No. 1 Maret 2013.

Richard L. Daft, New Era of Management (Canada, Printed, 2010), h.7 45 
Robbins Mary Coulter, Management (London: Pearson Education Limited, 2012), h.232

Serva, M. A., \& Fuller, M. A. "Aligning what we do and what we measure in business schools: Incorporating active learning and effective media use in the assessment of instruction". Journal of Management Education, 28, 2010 hh. 19-3

Stephen P. Robbins, Management Tenth Edition (Prentice Hall, Pearson, 2009), h. 415
Stewart-Wingfield, S., \& Black, G. S. (2005). "Active versus passive course designs: The impact on student outcomes". Journal of Education for Business81, 2005, hh. 119-125.

Yoder, J.D., dan Hochevar, C.M. Encouraging Active Learning Can Improve Students'Performance on Examinations. Teaching of Psychology, 2005, 32 (2), 9195.

Zayapragassaraszan and Santosh Kumar. Active Learning Methods. NTTC Bulletin (ISSN 2250-396X) 2012; 19(1):3-5. 